\title{
Missugust omakultuuri hoiame tantsupidudel? ${ }^{1}$
}

\begin{abstract}
Sille Kapper
Teesid: Missugust rolli etendavad pärimusliku tantsimisega seotud teadmiste ja oskuste säilitamisel ning edasikandmisel nüüdisaja Eestis üleriigilised üld- ja noorte tantsupeod? Millised pärimustantsu ideelised ja teostuslikud aspektid leiavad tantsupidude protsessis tähelepanu, mis heidetakse kõrvale ja miks? Artikli aluseks on minu tantsuetnograafilised välitööd aastatel 2008-2015 kahes osaliselt kattuvas tantsumaailmas: nendeks on pärimuslik tantsimine ja rahvatantsuharrastus, kusjuures viimane hõlmab tänapäeva Eestis üsna möödapääsmatult ka osalemist tantsupidudel. Uurimus näitas, kuidas meie ise - pidude loojad, osalejad ja vaatajad - tantsupidude protsessi käigus hoides kujundame ka neid institutsionaalse tõe režiime, mis teinekord jätavad varju alternatiivsed, kuigi omakultuuri säilitamisel ja edendamisel samuti olulised teadmised.
\end{abstract}

Märksõnad: agentsus, omakultuur, pärimuslik tantsimine, rahvatantsuharrastus, tantsumaailm, tantsupidu

\section{Sissejuhatuseks}

Artiklis käsitlen tantsupidude mõiste raames pidevat protsessi, millele suurem avalik tähelepanu saab Eestis enamasti osaks seoses valdkonna tippsündmustega - kord viie aasta tagant ${ }^{2}$ Tallinnas tuhandete tantsijate osavõtul toimuvate üleriigiliste üld-ja noorte tantsupidudega. Nende pidude ettevalmistustöö algab korraldus- ja kunstilistel meeskondadel ligikaudu kaks ja pool aastat enne peo toimumist, juhendajad ja rühmad alustavad konkreetse repertuaari õppimist umbes aasta enne pidu. Enamik rahvatantsukollektiive jätkab ka pidude vahel regulaarselt harjutamist ja iseseisvaid esinemisi. Samuti leiavad vaheaastatel aset mitmesugused väiksemad tantsupeotunnustega ${ }^{3}$ ühisüritused erinevates Eesti paikades ja ka välismaal elavate eestlaste seas.

Massilisuse ja tsüklilisuse kõrval iseloomustab tantsupidusid repertuaarivalik, mis ulatub "kõige iidsematest stiilidest kaasaegsete töötluste ja individuaalloominguni ja esindab ühiskonna esteetilisi ja sümboolseid väärtusi teatud 
ajalises muutumises, säilitades samas traditsioonilise repertuaari kui inspireeriva" (Kuutma 2002). Missugused repertuaari traditsiooniliseks nimetatud aspektid tänastel tantsupidudel kasutatava koreograafilise loomingu autoreid inspireerivad, seeläbi ka säilides ja levides, on esimene pool käesoleva artikli uurimisküsimusest. Loogiliselt huvitub küsimuse teine pool sama protsessi käigus unustusse jääma kippuva teadmuse sisust ja unustamise põhjustest. Artikli eesmärk on esmalt vaadelda, missugust omakultuuri saab edasi kanda tantsupidude traditsioon ning seejärel näidata, milliste omakultuuri aspektide jaoks tantsupeo laadne suurüritus kõige kohasem formaat ei ole.

Rahvatantsijate suurpeod toetavad pideva harrastustraditsiooni toimimist, hoides alal rühmade kooskäimise ja meeskonnatöö motivatsiooni ning pakkudes tantsijatele kõrge emotsionaalse väärtusega ühisesinemise võimalusi. Kohalike, maakondlike, linnade, valdade, soospetsiifiliste, liigipõhiste, talviste, sise- jt tantsupidude ja -peokeste rohkus ${ }^{4}$ näitab, et tantsupidu kui avalikkuses küllaltki nähtava ja suhteliselt suuri rahvahulki hõlmava tantsusündmuse formaat on omandanud kindla positsiooni tänapäeva Eesti omakultuuri hoidmisel ja kujundamisel ning omakultuuri olemust kirjeldavate arusaamade väljendamisel. Sellepärast ongi oluline teadvustada, missuguseid omakultuuri hoovusi tantsupidude protsess endaga kaasas kannab ja mida mitte.

Artikli esimeses osas annan ülevaate uurimisvälja kesksetest mõistetest, uurimisstrateegiast ja metodoloogiast, seejärel aga keskendun järgemööda kolmele alateemade ringile, mille kaudu avan omakultuuri, pärimusliku tantsimise ja tantsupidude suhteid. Selle analüütilise põhiosa lõpetuseks pakun mõned loogilised järeldused ja kokkuvõtte, kuidas toimib omakultuuri hoidmine tänapäeva tantsupidudel.

\section{Omakultuur, pärimuslik tantsimine ja tantsupeod}

Omakultuuri defineeritakse mitmeti. Eesti keele seletava sõnaraamatu (2009) veebiväljaanne annab vasteks nii rahva- kui rahvusliku kultuuri. Juri Lotmani (1999: 46) käsitluses eeldab omakultuuri kui idee sünd kultuuri jõudmist välise kirjelduse objekti asemel nn enesekirjelduse tasandile, kus algab rahvusliku kuuluvuse ja kultuuriliste eripärade tunnetamine ning selle põhjal "oma” ja "võõra" kultuuri eristamine. Niisugune omakultuur on vaadeldav kui üks kultuuri muutumise käigus formeeruv kihistus, osa kultuurist - "inimestevaheline suhtlemine, mille käigus kasutatakse olemasolevat sotsiaalset kogemust ning toodetakse uusi tähendusi, toetudes omaksvõetud uskumustele, normidele, arusaamadele" (Aru 2011: 137), tantsimine on omakorda üks osa sellisest suhtlemisest. Pärimuslik tantsimine ja suured tantsupeod on kaks põhimõtteliselt 
erinevat omakultuuri ilmingut, mis ühte ja samasse kultuurikihistusse kuuluvana rikastavad inimeste suhtlemist kumbki erinevate kogemuste ja tähenduste ning nendega seotud väärtuste, hinnangute ja hoiakutega.

Pärimuslikuks peetakse nüüdisajal sellist tantsimist, mis mingi tunnuse poolest vastab tänapäeva inimese kujutlustele tantsust endisaegses talukultuuris. Seda kujutlust võivad toita liikumistekstis äratuntavad minevikulised motiivid ja kinnipidamine kogukonnasisestest reeglitest või vastupidi, tantsu improvisatsiooniline ja varieeruv iseloom või hoopis tantsu kommunikatiivne funktsioon, mis pärimustantsu puhul arvatakse suunduvat pigem tantsijalt tantsijale või vähemalt kogukonna sisse, kui välisele vaatlejale (Kapper 2013: 92).

Pärimuslikule tantsule moodustavad tänapäeval aga teistest nüüdisajal viljeldavatest rohketest tantsuliikidest jõulisema taustsüsteemi just tantsupeod. Praeguseks veidi rohkem kui 80 aastat ${ }^{5}$ kestnud massitantsupidude traditsiooni jõud seisneb selle ulatuses ja avalikus nähtavuses. Massilisus on olnud üheks tantsupidude korralduslikuks ja lavastuslikuks põhimõtteks alates nende ajaloo algusest. Kümnel viimasel üldtantsupeol (1970-2009) on väljakul olnud üle 7000 esineja $^{6}$ (75 aastat ... 2009: 275), 2014. aasta peol oli neid Eesti Laulu- ja Tantsupeo Sihtasutuse väitel 10082 (Uudiskirjad 2014). Sotsioloogiline uuring "Minu laulu- ja tantsupidu" kinnitas, et viimase kümnendi "tantsupidudel on osalenud $10 \%$, publiku hulgas olnud $36 \%$ ja ülekandeid jälginud $77 \%$ rahvast" (Lauristin \& Vihalemm 2013: 4) - niisiis on tantsupidude ühiskondlik kõlapind vähemalt potentsiaalselt väga lai, kolmveerand Eesti elanikkonnast on tantsupidu vähemalt näinud ja omab sellest suursündmusest mingisugust ettekujutust.

Seetõttu on tänapäeval nii tantsijate kui ka vaatajate kujutlused endisaegsest talupojatantsust tugevasti mõjutatud tantsupidude protsessis tekkinud kehakogemustest ja/või visuaalsetest muljetest. Rühmade regulaarse rahvatantsuharrastuse traditsioon Eestis kestab samuti juba mitu inimpõlve. Seejuures on osalemine tantsupidudel kujunenud kindlaks osaks rahvatantsust kui harrastustegevusest ja paljude rahvatantsurühmade tegevuse dominandiks. Samal ajal on rahvatantsurühmadesse liikunud osa pärimusliku tantsimisega seotud teadmiste ja praktiliste oskuste omandamisest. Suurt osa pärimustantsust nähakse läbi harrastustraditsiooni prisma, suurpidudeks õpitu on juurdunud tantsijate kehades ning lavadel või staadionidel nähtud esitusstiil tundub ootuspärane vaataja silmis. Nii ongi tähtis märgata, missugust rolli mängib tantsupidudel osalemine pärimusliku tantsimisega seotud teadmiste ja oskuste säilitamisel ning edasikandmisel rahvatantsuharrastajate seas ja nüüdisaja Eestis üldisemalt. Millised pärimustantsu ideelised ja teostuslikud ${ }^{7}$ aspektid leiavad tantsupeoprotsessis tähelepanu, mille heidame aga kõrvale ja miks? 


\section{Uurimisstrateegia ja -meetod}

Tantsimist kui inimestevahelise suhtlemise protsessi analüüsides on kohane siduda erinevate sotsiaal- ja humanitaarteaduslike lähenemiste võimalusi - nii pakub tantsupidude tähtsuse ja mõju vaatluseks enne üksikisiku tantsuteadmuse tasandile siirdumist hea lähtepunkti sotsioloogiline uuring "Minu laulu-ja tantsupidu", mille tulemusel toodi välja (laulu- ja) tantsupidude traditsiooni ühiskondliku tähenduse neli erinevat mõõdet - rahvustundeid väljendav rituaal, riiklik institutsioon, laulu- ja tantsukunsti suurfestival ning suguvõsa kokkutulek (Lauristin \& Vihalemm 2013: 46). Tantsuteadmuse ja -oskustega seotud küsimusi uurides keskendun siit edasi peamiselt kahele dimensioonile - tantsupidu kui riiklik institutsioon ja üks Eesti tantsukunsti valdkonna tippsündmus. Michel Foucault (1992) mõtetele toetudes kirjeldab Tõnu Viik $\mathrm{nn}$ institutsionaalset uurimisstrateegiat:

Uurijad on tähele pannud, et institutsionaalse võimustaatuse pälvinud tähendussüsteemid tõrjuvad kõrvale alternatiivsed. Mistõttu võib institutsionaalsetest tähendussüsteemidest rääkida kui tõe režiimidest, mis toodavad niisugust teadmist, mis on väljakujunenud ja võimul olevate institutsioonide huvides (Viik 2011: 69).

Tantsupidude protsessi toetab Eesti riik. ${ }^{8}$ Mind aga intrigeerib küsimus, missugused huvid ja mil moel suunavad neid sisulisi valikuid, mida me tantsupidude loomisel tantsijate, õpetajate, kunstilise meeskonna liikmete või korraldajatena teeme. Kas tantsupeo protsessi tõerežiimide kujunemist teadvustades võiksime näha neis peegeldumas ühiskonnas valitsevaid ideid ning nende märkamine omakorda toob nähtavale ka neid tõrjutud alternatiive, mis valitseva tõe režiimiga kokku pole kõlanud?

Minu uurimuse põhimeetodiks on tantsuetnograafiline osalusvaatlus kahes nn tantsumaailmas - termin 'tantsumaailm' piiritleb mingit laadi tantsimise selle sotsiaal-kultuurilises kontekstis (dance world, Wulff 2013). Pärimuslik tantsimine on antud juhul üks, rahvatantsuharrastus koos tantsupidudega teine tantsumaailm. Üks osa nendes maailmades tegutsevatest tantsijatest kattub, teine osa mitte. Uuritud perioodiks on aastad 2008-2015, mille jooksul toimus kaks üldtantsupidu (2009 ja 2014) ja üks noorte tantsupidu (2011), käimas on 2017. aastal toimuva XII noorte tantsupeo loomeprotsess.

Mõlemas maailmas oli sel perioodil minu osalustegevusi kaks: ise tantsimine ja õpetamine, viimase hulka loen ka tööd tantsupidude loovmeeskondades 2009. aasta peol olin vaid rühmaõpetaja, omades varasemast ajast ka liigijuhi ja assistendi kogemusi. 2011. ja 2014. aasta pidude juures töötasin liigijuhi assistendina, 2017. aasta peo protsessis olen pealavastaja assistent. Olen niisiis 
osalenud valdkonna arenguid suunavates tegevustes erinevatel tasanditel ja ühtlasi tantsijana väga isiklikult tunnetanud valitsevate tõerežiimide ja diskursustega seoses üleskerkivaid küsimusi. Igapäevane navigeerimine pärimusliku tantsimise ja tantsupidudel peamiselt kasutatava rahvusliku lavatantsu (autoritantsu) kehatehnika ja leksikate vahel teravdab mu uurijatähelepanu oma enda propriotseptiivse ${ }^{9}$ ja ka visuaalse ning auditiivse taju signaalidele, mistõttu tekivad võrdlusmomendid, seejärel küsimused ja vahel ka uus teadmine.

Ise tantsimine on tantsuetnograafi unikaalne viis kehalise teadmise saamiseks oma uurimisobjekti kohta, milleks antud juhul on pärimuslikule tantsimisele omaste kehaliste aspektide esinemine või mitteesinemine, sallitus või tõrjutus tantsupidude protsessis. Kehalise teadmise mõiste tähistab siin refleksiivset kehalist protsessi, kus teadmine kujundatakse meeltega tajutud liikumise kaudu (bodily knowledge, Parviainen \& Aromaa 2015: 2). Selline kehaline teadmine on olemas igal tantsijal, aga selle sõnastamiseks on vaja spetsiaalset kavatsust, kusjuures suhtlejate üksteisest arusaamist soodustab ühine kogemus. Sellepärast soodustab tantsuetnograafiat eriti õppekeskkond tantsutreeningud, -tunnid ja -koolitused, kus ühiselt kogetud kehalisi aistinguid ja tajusid püütakse ühtlasi suuliselt reflekteerida.

Samas on taju-, refleksiooni- ja analüüsiprotsessid tantsuetnograafias üksteisest raskesti eristatavad, nagu Sarah Pink (2009: 3) kirjutab sensoorse etnograafia kohta üldiselt, mistõttu ma ei ürita rääkida eraldi andmekogumisest ja -analüüsist, vaid käsitlen neid ühtse protsessina. Lisaks pöördub (multi)sensoorne, keha erinevate meelte tajul põhinev lähenemine tantsu puhul tihti uurija ja uuritavate vahelisi piire hägustavaks autoetnograafiaks (Jewett 2008: 47-72), kus kehalise teadmise allikaks on uurija vahetu kehaline tantsukogemus ja selle refleksioon. Tantsu kontekstis on nägemise ja kuulmise kõrval eriline kaal uurija somaatilistel ja propriotseptiivsetel aistingutel, mis muutuvad infoallikana rakendatavaks reaalse tantsimise kaudu. Kehalise teadmuse kujundamise kõrval on oma roll tantsuetnograafias siiski ka kirjalikul ja videograafilisel dokumenteerimisel. Selle käigus moodustub omapärane välismälu, mida uurija hiljem üle lugedes või vaadates analüüsib veel teist ja mitmendat korda, leides varem kujunenud teadmusele kinnitust või aina uusi kahtlusi ja küsimusi.

\section{Pärimustants kaotab tantsupeo massilavastuses oma keerukuse}

Tantsupidude repertuaari luues ja valides lähtub iga peo kunstiline meeskond eeskätt lavastuse ideestikust. Selle kõrval peetakse silmas ka pedagoogilisi põhimõtteid (tantsude ea- ja jõukohasust vastavale rühmaliigile) ning harras- 
tusrahvatantsu valdkonna üldisemaid arenguvajadusi, nagu need loovmeeskonnale peoettevalmistuse vastavas etapis parasjagu paistavad. Prioriteediks on siiski lavastusterviku loomine, mille teenistusse kogu valitav repertuaar ${ }^{10}$ peab rakenduma ja millest tulenevad ka need pärimustantsu elemendid või aspektid, millele pöördub konkreetse peo loojate, osalejate ja lõpuks ka vaataja tähelepanu. Väljakul etenduva lavastuse nägemine ettevalmistusprotsessi lõppeesmärgina kujundab ühe tõerežiimi, milles kõik otsused ja valikud peavad alluma lõpptulemuse vajadustele.

Tantsupidu iseloomustab ja eristab teistest tantsusündmustest ja -lavastusest üks spetsiifiline koreograafiline väljendusvahend - väljakujoonis, mis tekib suurte tantsijahulkade organiseeritud liikumisest ruumis. Näeb seda mõistagi vaid vaataja, mis tähendab, et järgmine tantsupeo tõerežiim lähtub eeskätt tantsu visuaalselt tajutavast väljendusvõimest. Et staadionimurule "joonistatud" pilt või muster saaks selge, publikule arusaadav ja mõjuv, on loogiline lavastuse loojate püüd vähendada visuaalset "müra", mis tulemust hägustaks. See on peamine põhjus, miks tantsupeotantsudes, olgu tegemist algselt pärimusliku tantsu või originaalse autorikoreograafiaga, on ühtlustatud nii tantsijate liikumised ja liigutused kui ka näiteks esinemiskostüümid (rahvarõivaid) ja muud nähtavad komponendid (nt rekvisiidid). Ent visuaalsusest alguse saanud ühtlustav režiim jätkub ka tantsu teistes komponentides kuni etteantud emotsioonini, mida esitaja peaks tundma ning väljendada püüdma.

Pärimustantsude väljakule lavastamisel on liigutuste ja liikumise ühtlustamise üks esimesi ja tavalisemaid võtteid valiku tegemine ühe konkreetse teisendi kasuks, sest kuigi paljude individuaalsete või ka piirkondlike variantide üheaegne tantsimine oleks sageli ka üksteist segamata võimalik, tekitaks see justkui liigset visuaalset müra, mis takistab puhta väljakujoonise loomist. Olen oma rühmade jt õpilastega harjutades märganud ühtluse režiimi sügavat juurdumist tantsupidude konteksti - kui kavas on ka pärimusliku tantsu variant või element, ei julge tantsija sageli kättki puusale panna või sealt ära võtta ilma õpetajalt igaks juhuks küsimata. Umbes sama sagedane on küsimus, mis jalaga alustada - ka selliste tantsude puhul, kus see tantsu õnnestumist kuidagi ei mõjuta. Tantsija võib teada, et pärimusliku tantsimise puhul vastaks ta neile küsimustele ise oma keha loogikat järgides, ent tantsupeo puhul eeldab täpset normi.

Suhteliselt kaugel distantsil istuva või tänapäeval lõpuks ka droonifilmi või -fotot nautiva tantsupeo pealtvaataja tarvis loodud lavastuse seisukohast on ühtlustamine loogiline ja eesmärgipärane otsus. Pärimuskultuuri jätkuvuse plaanis põhjustab tantsupidude protsessis aset leidev ühtlustamine aga olulisi muutusi: kui tantsijate ja juhendajate seas levib nüüd see üks väljavalitud tantsuvariant, kaob üsna kiiresti teadmine pärimustantsu muutlikkuse tra- 
ditsioonilisest ulatusest. Veelgi enam: üsna kergesti asendub see kujutlusega piirangute puudumisest. See tuleb pärimustantsu muutlikkuse vastandamisest tantsupeo üldisele reglementeeritusele, mida osalejad üldjoontes hästi teavad ja mõistavad, samal ajal kui pärimusteadliku varieerimise oskused ja arusaamad traditsioonis toimivate piirangute ja vabaduste iseloomust on jäänud üpris tagasihoidlikuks.

Pidude hästiorganiseeritud ja suurt hulka tantsijaid hõlmavate ettevalmistuste abil on üleriigiliste tantsupidude võimuses hoida käibes mõningaid üldise iseloomuga baasoskusi, mis on heterogeense pärimuse mõistmiseks ja praktiliseks edasikandmiseks ühelt poolt küll hädavajalikud, aga teisalt kujutavad endast ka ohtu: väheseid elemente või näiteks vaid ühte tehnikat teades tekib kergesti illusioon selle omateadmuse kõikehõlmavusest - ühelt poolt hakkab tantsijale üsna kiiresti tunduma, et ta juba teab ja oskabki enamvähem kõike pärimuslikuks tantsimiseks vajaminevat, teisalt kujutleb ta, et nood peamised üldoskused on rakendatavad igas pärimustantsusituatsioonis. Mõlemaid tundeid olen isiklikult veel mõned aastad tagasi (uurimisperioodi alguses aastail 2008-2009) üsna akuutsel kujul tundnud ning alles uurimisprotsessi käigus järkjärgult oma kehalisi teadmisi mitmekesistades avastanud, kui kitsad ja ekslikud on sellised arusaamad. Endiselt ka oma rahvatantsija tausta mäletades ja jätkuvalt igapäevaselt rahvatantsijatega suheldes julgen väita, et sellised lihtsustavalt enesekindlad mõtted ja tunded on omased suurele hulgale meist.

Ohtu kujutab endast niisiis eeskätt lihtsustav suhtumine, millest projitseerub kogu pärimustantsule kuvand, et see on väheste võimalustega ja kellegi välise poolt reeglistatud tantsuliik, mille õppimine selle ajaloolise tausta tõttu on pigem "kodanikukohus" kui põnev ja huvitav väljakutse. Alternatiivne teadmus pärimustantsu piirangute ja vabaduste kogukondlikust olemusest, individuaalse detailirikkuse allikatest ning erinevatest kehakasutuspõhimõtetest jääb massitantsupidude loomisel kõrvale. Tantsu suhtlusfunktsiooni sotsiaalsed ja intiimsemad toimimisvõimalused või tehniliselt keerukad, ent visuaalselt vähemärgatavad detailid pole väljakulavastuses vajalikud, pigem võivad osutuda segajaks. Näiteks osutuvad pärimustantsus sageli esinevad väikesed vertikaalsed liikumised tantsupeo kontekstis täiesti mitteasjakohaseks, sest nad ei võimalda tantsijate kiiret (horisontaalset) ümberpaiknemist ruumis ega paista kaugemalt vaatajale üldse välja.

Õpetajana kardan minagi tantsupeo protsessis osaleva tantsija jaoks asja mõttetult keeruliseks ajada. Äärmisel juhul jagan alternatiivseid ideid võimalikult tantsupeokaugetes kontekstides, et vältida segadusi. Teadmine tantsupeo mõistes ebavajalike või ebaoluliste detailide päritolust, tähtsusest ja lõpuks ka olemasolust üldse rahvatantsuharrastuse peavoolu, kuhu kuulub tantsupidu, vähemalt praegu uuritud perioodil ei sobi. 


\section{Tantsimise õppimine tantsupeo protsessis}

Tantsupeol eraldame ${ }^{11}$ osalejad vanuse, vahel ka varasema tantsukogemuse kestuse ja oskuste järgi, et arendada iga tantsijat, rühma ja rühmaliiki eaning jõukohase repertuaari õppimise teel. Kaugemas perspektiivis on selle eesmärgiga seotud siiras soov hoida üldist tantsupidude traditsiooni elava, toimiva ja arenevana. Repertuaari jagunemine rühmaliigiti tehnilise raskusastme või kunstiliste kriteeriumide (väljendatava idee, teema vm) alusel on üks tantsupeo loojate sisemistest tõerežiimidest. Erinevate liikide kasutamine on ka lavastuslikuks vahendiks, mis võimaldab luua või võimendada etenduse eri osade erinevaid meeleolusid ja värve.

Tantsupeo formaadis lavastuse ja tänapäevase organiseeritud õppeprotsessi seisukohalt on tantsijate liigitamine seega igati asjakohane tegevus. Tantsupidudel edasikantavat omakultuuri kirjeldades märkame aga, et nii ignoreerime pärimuskultuurile omast eeskujupõhist õppimist mitmekesises grupis, kus toimetulek eeldab õppijalt tugevat isiklikku initsiatiivi. Pärimuslikus keskkonnas pikema aja jooksul erinevaid eeskujusid jälgides ja järgida püüdes võtab kõige suurema vastutuse oma tantsu eest tantsija ise, katsetades ja kohandades oma kehale sobivaks mitmes erinevas esituses nähtud, tihti ka eri paarilistega kogetud tantsu. Oma sotsiaal-kultuurilises keskkonnas avaneb pärimustants õppijale tervikuna, kogu spektris koos vigade ja tippesituste, kogukonnas heaks kiidetu ja halvaks pandu (“õige" ja "vale”), vanemate ja uuemate moodidega jne. Tants muutub ka igas teostuses, mis kokku moodustab pideva ja lõputu õppeprotsessi, mida tantsija ise ei pruugi alati üldse õppimisena käsitleda. Küll tunnetab ta enamasti üsna suurt isiklikku valikuvabadust ning sageli ka sellega kaasnevat omandi- ja vastutustunnet oma tantsu eest.

Tantsupeo repertuaari ettenähtud viisil äraõppimine ja esitamine paneb suure vastutuse rühma juhile, aga ei soodusta iga osaleja isikliku agentsuse kujunemist, milleks tantsides loodav kehaline teadmine annaks häid võimalusi. Agentsuse mõiste tähistab siin ja järgnevas subjekti võimet käsitleda ennast agendi ehk sellise tegutsejana, "kes on võimeline praktiliseks arutlemiseks ning valikute tegemiseks" (Reiland 2009: 25). Agentsust on nähtud nii üksikisiku kui inimrühmade omadusena. Tantsu kontekstis on eraldi veel tantsija individuaalse, elava ja liikuva keha kui teadmusallika agentsus (Parviainen \& Aromaa 2015: 1) see, mis suures osas suunab isiksuse valikuid. Elava tantsijakeha individuaalne agentsus on olemas igasuguse tantsu puhul, igas tantsuliigis, -laadis või -stiilis, ent toimib ja areneb neis erineval määral. Tantsupeotantsija isiklik agentsus väljendub otsustes osaleda protsessis järjepidevalt vähemalt selle ühe tsükli jooksul ning olla selle käigus kuulekas, tähelepanelik ja täpne õppija, keskenduda, harjutada, eesmärgipäraselt pingutada nii isiklikult 
kui meeskonnas jpm, kuid selles, kuidas konkreetselt tantsida ja ka mil viisil tantsimist õppida, on üksiktantsija valikud üsna piiratud.

Suures osas seisneb tantsupeol tantsimine olemasoleva koreograafilise materjali võimalikult täpses reprodutseerimises, mistõttu on taastootmisele üles ehitatud ka protsessis osalevate rühmade õppetegevus, ja see seab raamid ka tantsija kehalise teadmuse kujunemisele ning kasutamisele.

Nüüdisaegne tantsudidaktika (nt Gibbons 2007) on juba mõne aja eest taasleidnud pärimuskultuurist tuntud võtted, kus olulise osa õppe- ja loomeprotsessi vastutusest võtab tantsija ise, aga tantsupidude protsessis need ei rakendu. Rühmades on suurem osa vastutusest tantsu omandamise eest asetunud väljapoole tantsijat. Autoriloomingu puhul ongi absoluutselt asjakohane, et esikohale seatakse koreograafi sõna, mida pidulistele vahendavad liigijuht (kooskõlas lavastuse vajadustega) ja seejärel otse tantsijatele juba iga rühma õpetaja. Ka õige-vale skaalal kaalumist tantsijal ette võtta ei tule, sest viimase instantsina peab otsustama vähemalt rühmaõpetaja, kuidas rühm mingit elementi tantsib, kui ka koreograaf/liigijuht pole täpsustanud või õppematerjalid jätavad mitmeid tõlgendamise võimalusi. Ühtluse reegel on väljakutantsu puhul kujunenud üsna kõikehõlmavaks, mistõttu tantsijapoolseteks otsusteks ei jää siin märkimisväärset võimalust ega ka vajadust.

Olukorda pingestab ajanappus ja konkurentsisituatsioon, milles enamus rühmi üld- ja noorte tantsupidude ettevalmistuste ajal on. Kuna peole pääseb enamasti vähem rühmi kui on soovijaid, on eelproovis esinemise eesmärk esitada tants (jah, ka väljendusrikkalt ja teemakohases meeleolus), ent seejuures kindlasti “õigesti”, st nii, nagu koreograaf on soovinud ja/või liigijuht õpetanud. Kui just tantsu kompositsioonis pole ette nähtud improvisatsioonilist osa (vahel on), siis tantsija omapoolsed lisandused tantsupeo kontekstis sallitud ei ole. Lavastuse vajadustele vastav visuaalselt ühtlane esitus saavutatakse kõrvalt vaatava ja hinnanguid andva õpetaja tagasiside abil, vahel täiendab seda peegel või video. Tantsija enese täpsemalt teadvustatud kehatunnetus tantsimise ajal aitab õppeprotsessile kahtlemata kaasa, ent põhimeetodiks see rühmaharrastuses ei ole. Rühmatöö ja piiratud ajaressursi tingimustes jääb tantsijakeha agentsus, individuaalse tantsija teravdatud tähelepanu oma keha liikumisele või asenditele ja sellest tekkiv unikaalne teadmine põhitähelepanu alt välja.

Tantsupeo protsessis on koreograafi ja õpetaja kätte üle läinud aga mitte ainult enamus tantsuteadmusest, vaid ka vastutus tulemuse eest. See sarnaneb olukorraga teisteski valdkondades, kus oma keha tunnetamise asemel usaldame rohkem spetsialiste ja kehaväliseid mõõdikuid, näiteks meditsiinis, tervisespordis või toitumises. Tõerežiimina kipub siin esile ihalus mingi neutraalse või objektiivse hindaja või vähemalt hindamiskriteeriumi järele. Võib öelda, et tantsupidu peegeldab siin ühiskonna üldist hoovust, kus inimeste agentsus 
ehk võime järele mõelda ning tegutseda isiklike kehalis-vaimsete otsustus- ja valikukriteeriumide põhjal on väike.

Eelneva taustal väidan aga, et tantsupidude protsessis osalemine on kõigest hoolimata pigem lihtne - sarnaselt eneseabikirjandusega öeldakse siin täpselt ette, kuidas käituda või liikuda, et saavutada soovitud tulemus. Tantsurühma juhendajana olen tantsupeohooaegade eel (täiskasvanute õpetajana viimati sügisel 2013) enda juures selgelt märganud väikest mugavat rahulolu, mis kaasneb võimalusega täita etteantud ülesandeid, selmet ise eesmärke leida ja teekonda valida.

\section{Eesti mitmekultuurilisus ja eesti tantsupeod}

Tulenevalt üld- ja noorte tantsupidude üleriigilisuse põhimõttest ja massilisusest võiks tantsupidude protsessi tarvis pärimusmaterjali valides tähelepanu leida eeskätt traditsioonilises ühiskonnas laialdasema geograafilise levikuga aines. Oleks üsna loogiline, et sellise materjali tunnistaks mingil moel omaks suurem osa tegelaskonnast, samuti vaatajad. Reaalses töös ei ole mina siiski sellise valikupõhimõtte realiseerimise tunnistajaks sattunud. Omaaegse üleeestilise levikuga tantsud või motiivid leiavad kasutust pigem juhuse läbi, mõnikord seetõttu, et need on ka tänaste tantsujuhtide seas laiemalt teada.

Oluliselt iseloomulikum on tantsupidudele ja minu meelest ka rahvatantsuharrastusele üldiselt teine tendents - pärimusliku tantsumaterjali kasutamisel ei paku meile tantsupidude loomisel enamasti huvi selle paikkondlik ${ }^{12}$ päritolu. Maksimaalselt jääb märge peole loodud autoritantsu aluseks olnud pärimusteate kogumise kihelkonnast kirjeldusteraamatusse, mõnikord ka õpetuse sissejuhatusse juhendajate seminaril või rühmade esimestes tundideski. Tuleb aga ausalt tunnistada, et sisulist huvi see fakt meie tantsuõpetajatele ja tantsijatele tänapäeval kuigivõrd ei paku. Nii ei käi tantsupeol kasutatavate pärimustantsuelementidega kaasas paikkondlikud eripärad esitusstiilis või -maneerides. Viimane asjaolu ei tulene ainult tantsupeo massilisest ja ühtlasest olemusest - tuleb omaks võtta, et Eestis ei ole ju viimase ajani erinevate paikkondade tantsu ajaloolisi esitusiseärasusi ka kuigi üksikasjalikult analüüsitud. Nii mõnegi Eesti Rahvaluule Arhiivi kogudes paljukajastatud piirkonna, nt Häädemeeste või Kuusalu (ERA II 114 jt käsikirjaköited) puhul on see audiovisuaalse materjali vähesuse või hilisuse (ERA DV seeria) tõttu nüüd juba ka keeruline, kuigi kindlasti mitte võimatu. Hea tahtmise korral on küll täna võimalik saada teaduslikult põhjendatud infot nt Kihnu (Rüütel \& Kapper 2015) või Pakri (Nm 44 jt) saarte tantsude spetsiifiliste esitusviiside kohta, ent ilmselt ei ole meie ühine tahtmine tantsupidude kontekstis paikkondlikke eri- 
pärasid esile tuua ka piisavalt suur, et selleks pingutusi teha, väljakujunenud tõerežiimis erinevusi ei vajata, need oleksid pigem tüliks.

Tantsupeo lavastuse formaati arvestades ei tule paikkondlikele erisustele keskendumine kasuks, vajalikum on ühtsustunde loomine, millele tantsude päritolupiirkonna esiletõstmine kaasa ei aita, sest sellega peaksid siis kaasnema ka erinevused liikumises. Pigem võib piirkondlike eripärade esiletõstmine tekitada asjatuid probleeme seoses omandiküsimustega, mille üle arutlemine seoses pärimustantsuga ei ole Eestis veel kuigivõrd hoogu saanud, kuid muude maade näitel ja jälgides praegu toimuvat väikekogukondade renessanssi ei pruugi jääda tulemata.

Tantsupidu on Eesti rahvusliku ühtsuse manifest ja identiteedi kinnitaja. Selles rollis toimivat järjekordset tantsupidu luues jätame teadlikult või ebateadlikult varju nii Eesti sisemise ja ajaloolise mitmekultuurilisuse kui ka kultuurilise mitmekesisusega seotud tänapäevaprobleemid. Võib-olla on tõesti veel vara rääkida tantsupidudel kaasaegsest argisest mitmekultuurilisusest, tantsupidu ei ole ilmselgelt aktuaalsete päevapoliitiliste teemade lahkamise koht, lisaks arvestagem ka iga peo loomeprotsessi mitmeaastast pikkust, aga sel ajal kui mujal maailmas juba kriitiliselt analüüsitakse riikides toimivat institutsionaalset mitmekultuurilisust (Nagle 2009), puudub see meil tantsupidusid vaadates sootuks. Tasakaalukus ja läbimõeldus, mis võiks iseloomustada institutsionaalselt suunatud tegevusi ja mis tantsupeo puhul üldiselt peabki paika, ei iseloomusta viimaste tantsupidude lähenemist mitmekultuurilisuse temaatikale. Aeg-ajalt on pidudel küll üles astunud mõned Eesti vähemus- või naaberrahvuste rühmad (läti, vene ja soome rühmad eraldi etteastetega XVIII tantsupeol "Meri" 2009, läti tantsijad eesti rühmade seas XI noorte tantsupeol "Maa ja ilm" 2011), aga need valikud on lähtunud konkreetsest lavastusest ja tuleb institutsionaalses üldplaanis liigitada pigem juhuslikuks.

Tantsupidude ettevalmistavaid arutelusid nii lavastusmeeskondades kui ka muudes ekspertrühmades iseloomustab Eestis nii tänase kui ka ajaloolise mitmekultuurilisuse märkamise asemel pigem isegi pärimuskultuuri välismõjude mahavaikimine, kerge hirm lavastuse loomisel kasutatava pärimusmaterjali võimaliku võõra päritolu ees ja soov panna rõhku võimalikult eestipärasena käsitletavale nii vormi kui ka sisu poolest.

Milles eestilikkus seejuures seisneb, on tunnetuslik, individuaalne ja ajas muutuv. Rohketes diskussioonides tantsupidude tähenduse, tavade ja tuleviku üle leitakse lõpuks alati see ühine, mis formeerubki osaks peo protsessis kinnistuvast, levivast ja osavõtjate poolt omaks võetavast tõerežiimist. Siin ilmneb institutsionaalsete ja isiklike huvide ühisosa, milleks tundub olevat soov tegutseda koos suure hulga inimestega ja tunnetada sellega oma jõudu, kogeda turvatunnet ning kinnitada rahvuslikku identiteeti. Koostegemise nimel on 
loogiline teha kompromisse ja selle käigus tõrjutaksegi täiesti vabatahtlikult kõrvale alternatiivideed.

\section{Tantsupeo roll omakultuuri hoidmisel}

Eelpool kirjeldasin, kuidas meie ise - pidude loojad, osalejad ja vaatajad - tantsupidude protsessi käigus hoides loome neid tõerežiime, mis teinekord jätavad varju alternatiivsed, kuigi omakultuuri säilitamisel ja edendamisel olulised teadmised. Osaluskogemused ja eneseanalüüs nii kunstilise meeskonna liikme, tantsurühma juhi kui tantsijana annab kinnitust, et peoprotsesside peamiseks suunajaks on meil praegu massilavastuse loomine. Sellest dominandist lähtuvaid valikuid ja otsuseid analüüsides saab omakorda teha järgnevalt käsitletavaid järeldusi.

Kultuuri (sh pärimuse ja omakultuuri) kohalike või kogukondlike ja individuaalsete eripärade edasikandmist tantsupidude protsess ei toeta, sest keskendub oma massilisuses pigem sarnasele. Pärimustantsule sageli omistatavat vabadust, mitmekesisust ja improvisatsioonilisust kipume tantsupidude protsessis käsitlema piirangute täieliku puudumisena, mis on nüüdisühiskonna üldist konteksti arvestades ootuspärane, ent lihtsustav, ühtlustav ja sellisena vaesustav lähenemine. Seda tuleks muuta, tasakaalustades üle-eestiliselt ühisele teadmusele osaks saavat tähelepanu paikkondlike erisuste, eri kogukondades toiminud reeglite ja individuaalsete vabaduste iseloomu, traditsioonilise improvisatsiooni ulatuse jmt kultuuri sisemist rikkalikkust kasvatavate ja sidusust loovate teadmiste omandamisega. Seda ei ole tarvis teha tantsupidude õppeprotsessi käigus, sest massilavastuste loomisele see kaasa ei aita. Tantsupeo eripära ja mõjukus omakultuuri esitleja ja edendajana seisneb aga just masside sh nii väljakulavastustes osalejate kui vaatajate kõnetamises.

Teine oluline järeldus on, et tantsupeod toetavad ja võimendavad omakultuuri sisemist ühisosa, mis seisneb eeskätt rahvuslikes ja üldiselt positiivsetes väärtussõnumites, mis väljenduvad pidude pealkirjades, tüvitekstides, lavastuste narratiivides ja repertuaaris ning neile lisanduvas väikeses hulgas eestipäraseks peetavates kehalistes väljendusviisides. Tantsupidu raamistab ja toob jõuliselt esile tugevaid identiteedikinnitusi, millega meeleldi suhestavad omaenda rahvustunnete väljenduse nii osalevad tantsijad kui ka pealtvaatajad. Ma ei ole kindel, kuivõrd leidub tantsupidude repertuaaris ja loomeprotsessi ülesehituses üliheterogeense nüüdiskultuuri üldalaga sulanduvat ainest. Paratamatult asetub tantsupidu nii etendushetkel kui ka enne ja pärast seda oma aja nüüdiskultuuri konteksti, kuid kaasaegse ühiskonna probleemide käsitlemist tantsupeol ei võta ülearu mõistvalt vastu ei tantsijad ega publik, isegi kui 
lavastusgrupis on valupunktidele tähelepanu juhtimise tahe olemas (nt linna-ja rahateema XIX üldtantsupeol "Puudutus" 2014). Iga järgmise peo meeskond püüab eelmise kogemustest õppides kahtlemata teha uuesti ja targemalt. Kuna aga tantsupidu ei tee kunstiline meeskond, tantsijad ega vaatajad üksi, vaid kõik komponendid koos, osalevad kõik need grupid ka valitsevate tõerežiimide kujundamisel - järelikult omavad ka võimalust neid mõjutada.

Kolmandaks järeldan, et tantsupeo roll ei paista praegu olevat ka osaleja agentsuse kasvatamine. Sellest loobumine võib olla kasulik tantsupeo praeguse formaadi raames, ent ühiskondlikult laiemas ja pikemas perspektiivis ei pruugi osutuda jätkusuutlikuks. Arvestades pealekasvava põlvkonna "hedonistlikku eneseväljenduslikku orientatsiooni" ja eemaldumist "laulu- ja tantsupeo institutsionaalsest ja rahvuslik-ideoloogilisest tähendusest" (Lauristin \& Vihalemm 2013: 48) oleks siiski oluline leida ruumi tantsija vastutuse suurendamiseks. Seejuures tuleb märkida, et viimaste kümnendite õnnestunud tantsupeod on tõstnud rahvatantsuharrastuse populaarsust Eestis eeskätt just sellega, et inimesed on saanud osaleda kõrgel kunstilisel tasemel lavastuste loomisel ja nautinud etendamise publikumenu. Selles osas erineb meie olukord mõnevõrra näiteks Põhjamaade omast ja tundub pigem jätkusuutlik. Vanavanemate ja vanemate positiivsed elamused suunavad ka järjest uusi lapsi rahvatantsurühmadesse harjutama ning järjekordsed põlvkonnad õpivad omakultuuri tundma läbi tantsupeo tõerežiimide, kus enamik valikuid on nende eest juba ära tehtud. Sellest tulenevalt võiks lihtsustatult mõelda, et oluline on ette tehtud valikute kvaliteet (mis teatud määral kindlasti ongi), ent sellest tähtsamaks pean ma siiski ka tantsija kui vastutustundlikult valiku- ja otsustusvõimelise tegelase oskuste väärtustamist ja kasvatamist peo ${ }^{13}$ protsessis. Vastasel korral võib osalejate seas tekkida ja süveneda mitte ainult võõrandumine omakultuuri mitmekesistest pärimuslikest komponentidest, mis praeguseks on sündinud, vaid järgmisena ka rahvuslikku ühtsustunnet iseloomustavatest ja toitvatest väärtustest.

\section{Kokkuvõtteks}

Kõigil eeltoodud põhjustel tuleb tantsupeo riiklikku toetamist ilmtingimata jätkates selgesti väärtustada ka teisi tantsusündmusi ja -protsesse, mis pööravad tähelepanu neile aspektidele, mida tantsupidu käsitleda ei saa ega peagi. Tantsupidu oma massilisuses on küll teiste ettevõtmistega võrreldamatu suursündmus, kuid ei pea sellest hoolimata lahendama kõiki omakultuuri hoidmisel esile kerkivaid probleeme.

Uurimus näitas, et tantsupeo roll ei ole hoida kultuurilist mitmekesisust eri paikkondade või ka rahvusrühmade kultuuride mõttes, küll võib tantsu- 
pidu ennast näha ühe eripärase kultuurivormina, mis kannab edasi teatud osa omakultuurist. Seejuures on tantsupeo ülesandeks ja hästi täidetud osaks just rahvuslikku ühtsust peegeldavate väärtuste pühitsemine, mis on domineerivas populaarkultuuris levivate globaalsete väärtuste tasakaalustamiseks kahtlemata äärmiselt vajalik. Et aga ühtsus ei manduks ühetaolisuseks ja oma sihtrühma leiaksid ka tantsupeorežiimidega haakumatud tõed nagu näiteks pärimustantsu keerukus ja selle varieeruvuse või improvisatsiooni traditsiooniline ulatus, iseseisev eeskujupõhine õppimine ja toimetulek mitmekesises grupis, samuti Eesti ajalooline ja sisemine mitmekultuurilisus, on massiürituste kõrval väga vajalikud nišitegevused - intiimsemad festivalid, kodukontserdid, -etendused, perede, väikeste rühmade ja sõpruskondade koostegemised - ettevõtmised, mis ei hõlma kogu ühiskonda korraga, vaid nõuavad hoopis nii rühmadelt kui ka üksikisikutelt suutlikkust teha argumenteeritud valikuid. Oma väikese kogukonna omakultuuri leidmiseks, loomiseks, hoidmiseks ja arenguks vajalike otsuste tegemine kasvatab enesetunnetuse ning -juhtimise võimet seestpoolt väljapoole, tehes kokkuvõttes eneseteadlikumaks ja seeläbi tugevamaks kogu ühiskonna.

\section{Kommentaarid}

1 Artikkel on seotud ETF grandiga 9132 "Rahvatantsuharrastuse ja rahvatantsijate suurürituste roll omakultuuri hoidmisel". Kuna grandiprojekti fookus oli suunatud suurüritustele, keskendun käesolevas artiklis tantsupeo kui Eestis riiklikult toetatud ja rahvusvaheliselt UNESCO maailmapärandi nimekirja kantud traditsioonile. Väiksemate omakultuuri edasikandvate tantsusündmuste uurimise vajadus sai läbiviidud uurimuse käigus kinnitust ja on kavandatud realiseeruma edaspidi väljaspool antud projekti.

${ }^{2}$ Noortepeod ja üldpeod toimuvad erinevatel aastatel, nüüdisajal noortepidu kolm aastat pärast üldpeo toimumist ja järgmine üldpidu kaks aastat pärast noortepidu. Erinevatel põhjustel ei ole see rütm olnud pidude ajaloos siiski absoluutne, üldtantsupeod on toimunud aastatel 1934, 1939, 1947, 1950, 1955, 1960, 1963, 1965, 1970, 1973, 1975, 1981, 1985, 1990, 1994, 1999, 2004, 2009, 2014, noorte tantsupeod 1962, 1967, 1972, 1977, 1982, 1987, 1993, 1997, 2002, 2007 ja 2011.

3 Tantsupeo tunnustena on Angela Arraste oma magistritöös nimetanud vaatajale orienteeritud etenduse ja korraldava organisatsiooni olemasolu, järgnevate ja eri tasandite pidude süsteemi planeerimist, juhendajate eelkoolitusi, uute tantsude loomist lavastuse jaoks, eel- ja väljakuproovide toimumist, paljude rühmade üheaegset esinemist (massilisust) ja tantsujooniste kasutamist lavastuses, koostööd muusikutega, külalisesinejate ja rahvarõivaste kasutamist, hilisemal ajal ka esinejate valikut konkursi alusel (Arraste 2009: 23). Lisaks toob ta tantsupeole iseloomulike elementidena välja veel peoga seotud rituaalid nagu tule süütamine, rongkäik, juhtide tunnustamine jm (Arraste 2009: 48).

Väljaspool üld- ja noorte tantsupidusid, mida korraldab Eesti Laulu- ja Tantsupeo SA (ELT SA), toimuvaid tantsupeo-nimelisi sündmusi iseloomustavad paljud Arraste mainitud tunnused, kuigi mitte alati kõik. ELT SA on koostöös Eesti Rahvatantsu ja 
Rahvamuusika Seltsi ning Poliitikauuringute Keskusega Praxis tänaseks algatanud uue uurimisprojekti, mille eesmärk on "traditsioonilise tantsupeo olemuse määratlemine läbi selle olulisemate tunnusjoonte ja kriteeriumite sõnastamise” (ERRS 2015), ent kuni selle uuringu tulemuste selgumiseni lähtun Angela Arraste koostatud tunnuste loetelust.

4 Küsisin Eesti Rahvatantsu ja Rahvamuusika Seltsi esindajalt tantsupeo-nimeliste ürituste statistikat, kuid kahjuks see puudub. Oleks meelevaldne tuua välja üksikute valdade, linnade või maakondade pidusid, mis tänaseks toimuvad peaaegu kõikjal, seepärast olgu näidetena väljaspool üld- ja noorte tantsupidude süsteemi korraldatud tantsupidudest mainitud veel vaid mõned: uurimisperioodil toimusid meeste tantsupeod Rakveres 2010. ja 2015. aastal ning naiste tantsupidu Jõgeval 2011. aastal ning algasid ettevalmistused järgmiseks 2016. aastal korraldatavaks peoks, Soome-Eesti tantsupidu toimus Tamperes 2012. aastal, eelkooliealiste laste tantsupeod Viimsis 2012, Rakveres 2013 ja Haapsalus 2015, talviseid tantsupidusid peeti Viljandis, Tartus, Ida-Virumaal jne.

5 Vaatamata sellele, et tantsupeo tunnuseid kandis juba 1926. aastal toimunud esimene eesti omakultuuri õhtu, loetakse tantsupidude numeratsioonis kokkuleppeliselt esimeseks üldtantsupeoks 1934. aastal I Eesti Mängude raames toimunud võimlejate, rahvatantsijate ja pillimängijate ühisetendust (Arraste 2009: 23).

6 Õppeprotsessides osalejaid on rohkem, ent kõik soovijad esinema ei pääse, sest peost osavõtjate arv on piiratud nii esinemisväljaku mõõtmete kui ka mitmesuguste muude logistiliste ja korralduslike tingimustega.

7 Idee ja teostus ehk kontseptsioon ja realisatsioon (concept and realization) on Norra-Leedu tantsuteadlaste tandemi Egil Bakka ja Gediminas Karoblise (2010) järgi tantsuteadmuse kaks keskset ja lahutamatut mõõdet.

8 Tantsupidusid korraldava organisatsiooni, Eesti Laulu- ja Tantsupeo Sihtasutuse asutajaks on Eesti Vabariik, kelle nimel teostab asutajaõigusi kultuuriministeerium. Sihtasutusel on iseseisev eelarve (ELT SA põhikiri). Ajakirjanduse andmetel oli näiteks 2014. aasta üldlaulu- ja tantsupeo eelarve kolm miljonit eurot, millest pool tuli eelnevate pidude piletitulust ja pool riigieelarvest (Järvekülg 2014), sihtasutus on oma kodulehel sama peo järel avaldanud tänu ka hulgale eraettevõtetest toetajatele (Täname ... 2014).

9 Propriotseptsioon ehk süvatundlikkus on Meditsiinisõnastiku (1996) järgi võime tunnetada jäsemete asendit neid vaatlemata, samuti tasakaaluaistingud. Tantsu autoetnograafilisel uurimisel laieneb propriotseptiivse taju mõiste minu silmis kogu keha ja selle erinevate osade asendite tunnetamisele.

10 Tänapäeva tantsupidudel vormistub kogu kasutatav repertuaar autoriteostena, sh pärimustantsust ja -muusikast lähtuvad töötlused, mis läbivad seadmise ja lavastamise loomingulise protsessi ning üldjuhul fikseeruvad lõpuks kindlale taasesitatavale kujule. Sellepärast saab tantsupeo lavastuse kontekstis rääkida vaid kas pärimustantsu motiivide või elementide kasutamisest, seadest, töötlusest jmt.

${ }^{11}$ Rühmaliikide jaotuse üle ei otsusta tänapäeval tantsupidude loovmeeskonnad üksi, siin räägib kaasa ka suurte kogemustega rahvatantsujuhtidest koosnev ERRSi mentornõukoda, samuti valdkonna teisedki tegijad. Üldjoontes on jaotus küll pidevalt enamvähem sama, aga iga konkreetse peo raames võib tekkida väiksemaid täpsustusi, sh ka uusi või ajutisi lisa- ja eriliike.

${ }^{12}$ Erandiks on seto tants, millele rohkem viidatakse, seda vahel põhjusega ja teinekord ka ilma, nimelt kui töötlus(ed) on tantsu kogukonna kultuuri tänaste kandjate jaoks tundmatuseni muutnud. 
13 2017. aastal toimuva XII noorte tantsupeo ettevalmistustes sisaldub ka järgmine katse selles suunas edasi liikuda - lisaks lavastusse kuuluvate autoritantsude õppimisele on kavas osalejate seminarides, eelproovides ja õppematerjalides tähelepanu pöörata ka pärimustantsuteadmistele ja -oskustele, mida tantsija saaks rakendada iseseisvalt näiteks tantsupeoga ühises ajaraamis toimuval rahvamuusikapeol või mujal. Eelpool esile toodud üle-eestilise $v s$ paikkondliku pärimuse küsimused jäävad sellegipoolest kehtima ka siin.

\section{Arhiiviallikad}

ERA II 114 - Eesti Kirjandusmuuseumi Eesti Rahvaluule Arhiiv. R. Põldmäe, U. Toomi 1935 .

ERA DV - Eesti Kirjandusmuuseumi Eesti Rahvaluule Arhiivi DV 109-119.

Nm 44 - Nordiska museet (Põhjamaade muuseum Stockholmis). Bröllop på Rågö Per Söderbäck 1934.

\section{Kirjandus}

Arraste, Angela 2009. Tantsupeod eestlaste kultuuriloos. Magistritöö. Tallinn: Tallinna Ülikooli Kunstide Instituut, koreograafia osakond.

75 aastat 2009 = Arraste, Lille-Astra \& Adamson, Ilma \& Ammas, Anneli \& Feršel, Ülle \& Tiis, Kadri \& Žigurs, Juris \& Valner, Kadri (koost). 75 aastat eesti tantsupidusid. Tallinn: Varrak.

Aru, Krista 2011. Omakultuuri küsimus toimetajakeskses ajalehes "Postimees": isamaalisest meelest kultuurisisese dialoogini. Veidemann, Rein (koost). Kõnetav kultuur. Tallinn: Eesti Keele Sihtasutus, lk 135-162.

Bakka, Egil \& Karoblis, Gediminas 2010. Writing “a Dance": Epistemology for Dance Research. Yearbook for Traditional Music 42, Ljubljana: International Council for Traditional Music, lk 167-193.

EKSS 2009 = Langemets, Margit \& Tiits, Mai \& Valdre, Tiia \& Veskis, Leidi \& Viks, Ülle \& Vol, Piret (toim). Eesti keele seletav sõnaraamat. Tallinn: Eesti Keele Instituut (http://www.eki.ee/dict/ekss/index.cgi?Q=omakultuur\&F=M - 11. veebruar 2016).

ELT SA põhikiri = Eesti Laulu- ja Tantsupeo SA kodulehekülg (http://sa.laulupidu.ee/ sa-uldinfo/pohikiri/ -11. veebruar 2016).

ERRS 2015 = ERRS üldkogu protokoll 05.12.2015. Lisa 8. Tantsupeo analüüsi tutvustus. Eesti Rahvatantsu ja Rahvamuusika Seltsi kodulehekülg errs.ee (http://www.errs.ee/ public/LISA_8_-_tantsupeo_analuusi_tutvustus.pdf - 11. veebruar 2016).

Foucault, Michel 1992. Tõde ja võim. Intervjuu Alessandro Fontana ja Pasquale Pasquinoga. Vikerkaar 11. Tallinn: Kultuurileht, lk 31-52. 
Gibbons, Elizabeth 2007. Teaching Dance. The Spectrum of Styles. Bloomington: AuthorHouse.

Jewett, Laura M. 2008. Autoethnography, Curriculum, and the Semblance of Intimacy. New York: Peter Lang.

Järvekülg, Madis 2014. Pool suurpeo eelarvest tuli piletitulust. Postimees, 7. juuli (http://elu24.postimees.ee/2849543/pool-suurpeo-eelarvest-tuli-piletitulust?id=2849543 15. veebruar 2016).

Kapper, Sille 2013. Muutuv pärimustants: kontseptsioonid ja realisatsioonid Eestis 2008-2103. Tallinna Ülikool, Humanitaarteaduste dissertatsioonid 35. Tallinn: Tallinna Ülikooli Kirjastus.

Kuutma, Kristin 2002. Eesti, Läti ja Leedu laulu- ja tantsupeo protsessi traditsioonid ning sümbolid. UNESCO Eesti Rahvuslik Komisjon. Vaimse kultuuripärandi kaitse konventsiooni nimekirjad. Eesti, Läti ja Leedu laulu- ja tantsupidude traditsioon (http:// sa.laulupidu.ee/wp-content/uploads/2015/01/Laulu-tantsupeod_ESTLATLIT-UNESCOtaotlus.pdf - 15. veebruar 2016).

Lauristin, Marju \& Vihalemm, Peeter 2013. Minu laulu- ja tantsupidu. Sotsioloogilise uuringu aruanne. Eesti Laulu- ja Tantsupeo SA. Tartu (http://2014.laulupidu.ee/wpcontent/uploads/2014/01/Laulupeo-uuringu-aruanne-oktoober-2013.pdf - 15. veebruar 2016).

Lotman, Juri 1999. Semiosfäärist. Tallinn: Vagabund.

Meditsiinisõnastik 1996 = Bogovski, Pavel \& Kull, Rein (toim). Meditsiinisõnastik: eestikeelsed terminid koos seletuste ning ladina, inglise ja soome vastetega. Tallinn: Medicina.

Nagle, John 2009. Multiculturalism's Double Bind. Creating Inclusivity, Cosmopolitanism and Difference (Urban Anthropology). Surrey: Ashgate.

Parviainen, J. \& Aromaa, J. 2015. Bodily knowledge beyond motor skills and physical fitness: a phenomenological description of knowledge formation in physical training. Sport, Education and Society (doi: 10.1080/13573322.2015.1054273).

Pink, Sarah 2009. Doing Sensory Ethnography. London: Sage Publications Ltd.

Reiland, Indrek 2009. Mis on filosoofia? Studia Philosophica Estonica 2.1, lk 19-31 (http://www.spe.ut.ee/ojs-2.2.2/index.php/spe/article/viewFile/15/36 - 15. veebruar 2016).

Rüütel, Ingrid \& Kapper, Sille 2015. Kihnu tantsud. Tartu: Eesti Kirjandusmuuseumi Teaduskirjastus.

Täname ... 2014 = Täname toetajaid ja partnereid 2014. XXVI laulu- ja XIX tantsupidu Eesti Laulu- ja Tantsupeo SA kodulehekülg (http://2014.laulupidu.ee/uudised/tanametoetajaid-ja-partnereid/ - 15. veebruar 2016).

Uudiskirjad 2014 = Uudiskirjad. XXVI laulu- ja XIX tantsupidu. Eesti Laulu- ja Tantsupeo SA kodulehekülg (http://2014.laulupidu.ee/kulaline/uudiskirjad - 15. veebruar 2016).

Viik, Tõnu 2011 Kultuuriline pööre. Tamm, Marek (koost). Humanitaarteaduste metodoloogia. Uusi väljavaateid. Gigantum Humeris. Tallinn: TLÜ Kirjastus, lk 59-79.

Wulff, Helena 2013. Dance Ethnography. Oxford Bibliographies Online (http://www. oxfordbibliographies.com/view/document/obo-9780199766567/obo-9780199766567-0079. $\mathrm{xml}-15$. veebruar 2016). 


\title{
Summary
}

\section{What kind of Estonian culture is fostered at dance celebrations?}

\author{
Sille Kapper
}

Keywords: agency, dance celebration, dance world, folk dance as a hobby, traditional dancing

Estonian Song and Dance Celebrations take place every five years, involve thousands of participants and great audiences in venues or via the media. In Estonia the tradition of dance celebrations as well as (stage) folk dance in hobby groups dates back to the beginning of the twentieth century. In the learning processes and programmes of dance celebrations traditional folk dance is used in the format of some single elements or features only.

In a situation like this it is important to ask what role dance celebrations play in preserving and passing on the knowledge and skills connected with traditional dancing in contemporary Estonia. Which concepts and realisations of a dance may be compatible with the process of dance celebrations, and which of them are left aside and why? The article is based on the author's dance ethnography (2008-2105) in two dance worlds, which partially overlap each other: it is the traditional folk dancing on the one hand, and the (stage) folk dance as a hobby, including participation in dance celebrations, on the other.

The study shows that it is ourselves who create those institutional truth regimes that promote certain ideas while overshadowing alternative knowledge, although important for the preservation and sustainable development of our national culture. The main conclusions of the study are as follows:

Dance celebrations do not support the propagation of the plural and diverse nature of traditional culture (on the example of traditional dancing) because their principal output, the massive productions, are not designed for that purpose, have other strengths and also other requirements in connection with its specialty to address large crowds at rather long distances. The format of dance celebration suits well for highlighting the positive, unified, and common values of national culture, while social criticism is not an attitude readily adopted, either by participant dancers or by the audience, even if such an approach is proposed by a creative team. Although the agency of the lived body as a source of knowledge can generally be well utilised in increasing one's self-awareness in dancing, the dance celebration processes do not enhance the personal agency of participant dancers - most choices are made by the artistic teams and group leaders while the dancers' main task is to obey the rules. This could be seen as a point of concern because low agency, meaning here unwillingness and poor ability to make intended decisions, may easily lead to alienation from the values important for the tradition of dance celebration itself and Estonian national culture as a whole. 